\title{
Special Capitation Fund for Remote Areas: Is that Useful?
}

\author{
Karl Pasaribu ${ }^{1, *}$, Firdaus Hafidz ${ }^{1}$ \\ ${ }^{I}$ Faculty of Medicine Public Health and Nursing Universitas Gadjah Mada Yogyakarta, Indonesia \\ "Corresponding author. Email: karl.frizts.p@mail.ugm.ac.id
}

\begin{abstract}
Ministry of Health Regulation Number 90 of 2015 regulates the special capitation fund were paid for health facilities in remote and very remote areas which estabilished by district head. Head of the North Nias District issued letter of decree Number 640.2/K/Year/2016 estabilish seven sub-districts in North Nias district as remote and very remote areas, with the result that start from October 2017 receive special capitation payment. There have been no research regarding the benefit and impact of special capitation fund. Objective: This study aims to explore benefit and impact of special capitation fund in North Nias District. Method: This study used a descriptive qualitative research design with a case study research method. This study has conducted in seven Public Health Centre (PHC) that receive special capitation fund and in District Health Office North Nias District. Result: Special capitation fund have positive impact in enhancement of PHC staff motivation because of income increase and support local goverment's budget. However, special capitation has a negative impact such as the absence of PHC referral lowering due to no specific target in its implementation. The absence of specific regulations resulted in no targets and clear achievements of the special capitation fund. Puskesmas can't get more benefits from special capitation fund caused by there is no authority from regulation and limited of human resources. Conclusion: Special capitation was not gave a positive impact to puskesmas as an istitution and has not succeeded to motivate service quality improvement, include interest of health workers to remote areas. But gain benefit's for motivating puskesmas health workers to serve more. Recommendation: The local government should design a specific regulation to give more authority to puskesmas for implementing special capitation fund or modify the special capitation fund allocation for health service quality improvement in remote areas which can be measured with clear indicator and specific targets.
\end{abstract}

Keywords: remote area, special capitation, implementation, benefit

\section{INTRODUCTION}

The national health insurance policy has been implemented for four years and in fact, some problems are still found. The problems were not only found in the central government level but also in regional level. The increasing number of BPJS health participants in the districts causes higher health services demand while the health care workers were not distributed evenly in the districts [1]. The total of health care workers in $3 \mathrm{~T}$ regions (frontier, outermost, and least developed regions) was only 154.792 people or around 13, 4 of the total health care workers in Indonesia. The $3 \mathrm{~T}$ regions covered $27,8 \%$ of districts/cities [2]. In other words, the health care workers are not distributed evenly, especially in 3T regions and it has impacts on the poor health services for the community.

A study conducted in India found that doctors working in remote regions expect higher income to be able to survive in that regions as the current earning was not sufficient. They wanted improvement on management, budget transparency, better policies, and not involved in political intervention [3]. Furthermore, a study in Ghana revealed that the policy makers should design specific incentive for health care workers in $3 \mathrm{~T}$ regions for example short tenure and higher income [4].

The Regulation of the Minister of Health Number 90 of 2015 on the Implementation of Health Services in 3T regions highlights mandates for BPJS Kesehatan to provide special capitation rates to health facilities in $3 \mathrm{~T}$ regions in accordance with the regent's decree. The special capitation rates are stipulated in the Regulation of the Minister of Health Number 52 of 2016 on Standard Health Services Rates in the National health Insurance Program. The rate is Rp.10.000 for health facility with a doctor and Rp.8.000 for health facilities with a nurse or midwife. The payment for a health facility with less than 1000 participants is counted as 1000 participants.

The Regent Decree Number 640.2/310.K/2016 concerning Determination of Health Facilities in 3T regions Nias Utara District states reveals that seven puskesmas in Nias Utara district are categorized as remote and very remote regions. Thus, they have received special capitation funds since October 2017. As this special capitation policy has just been implemented, there was no report or study concerning on the special capitation funds in Nias Utara district. Based on this condition, a study about the special capitation funds is crucial. 
The objectives of this study are to identify impact the special capitation fund on the improvement of health services in puskesmas in Nias Utara district.

\section{METHOD}

This study is a descriptive qualitative with a case study design. The study involved seven puskesmas that received the special capitation funds and Nias Utara District Health Office. The puskesmas was Puskesmas Afulu, Puskesmas Alasa, Puskesmas Alasa Talumuzoi, Puskesmas Namohalu Esiwa, Puskesmas Lahewa Timur, Puskesmas Lahewa, and Puskesmas Tugala Oyo. The data were collected through interviewing the informants. The interviewed were recorded and documented in order to maintain the consistency and quality of the data.

All collected data from all informants were analyzed. The interviews transcript data were reduced and coded based on related information. After the coding, the data were categorized and interpreted. Finally, the data were presented in the form of narration for drawing conclusions. The triangulation was also carried out to maintain the data credibility. This study was approved by Medical and Health Research Ethics Committee Faculty of Medicine Public Health and Nursing - Dr. Sardjito General Hospital.

\section{RESULTS AND DISCUSSION}

Special capitation funds was utilized in accordance with the Regent Decree Number 640.2/310/K/YEAR/2016 concerning the Allocation of Special Capitation Funds of National Health Insurance Program for Puskesmas in Nias Utara district with $60 \%$ for health services and $40 \%$ for operational supports (20\% for medicines and consumables supplies and $20 \%$ for other operational supports). This allocation is in line with the utilization of capitation funds proposed by Goodson et al., (2001) [5]. He states that the funds were allocated based on certain percentage for primary services. In other regions in Indonesia, some puskesmas did not allocate the same proportion, for example a study conducted by Heriawan (2016) found that the utilization of capitation funds in Seluma district was $75 \%$ for health services, $20 \%$ for medicines and consumables supplies, and $5 \%$ for other operational supports [6].

The Special Capitation fund was not impact fund utilization in Puskesmas, because there is no difference fund absorption with the normal capitation. It can be seen from the following quote:

"The realization of capitation fund is the same as $i$ said before, for health services it has reached $99 \%$ and for operational support is lower or only reach 50$60 \%$ "(R2)

Puskesmas hampered to get more benefit from special capitation fund, because they can't procure directly. With following quote:
"Sure, there is a challenge. $20 \%$ for consumables supplies and medicines. There is no certified unit for procurement in puskesmas, so the procurement is carried out by the district health office." (R3).

Limited human resource, educational background and poor understanding about the utulization of special capitation also become a barrier for puskesmas to explore benefit from special capitation fund. It can be seen from following quotes:

"I think the understanding on fund management is low. The treasurers has not understood it well. "(R4).

"The understanding is low as the JKN funds are managed by a nurse. The nurse has no background knowledge on managing funds." (R5)

The special capitation funds gave positive impacts such as improve health services in puskesmas, strengthen the available health services, and improve the access to health services. It can be seen from the following quotes:

"In the past, when a patient come telling their condition and then we only give them medicines. Now, we need to check the patient's condition (blood pressure, weight, etc.) first and then ask the doctor to check further. So, it's better now." (R7)

"The funds are beneficial for supporting our programs, for example to support Mother and Child Health $(\mathrm{MCH})$ program through providing monitoring and guidance for pregnant women." (R1)

"The impact of the capitation funds is outstanding. For example, the puskesmas workers become more diligent to come to the health facilities. Previously they only come 3 times a week, and now they come 5 times a week." (R3)

"The number of patients' visit to puskesmas is higher compared to the previous year. So, there patients' visit increases." (R6)

This special capitation funds made the health care workers more diligent and it encouraged them to provide better services for the patient. The condition above is in accordance with a study conducted by Basu et al., (2017) that found higher capitation funds have impact on primary health care facilities in which they could maintain their quality services [7]. Luft (2009) revealed that the provision of incentive will support innovation in health services. It in lines with the result of this study the capitation funds support the implementation of some field programs that previously could not be carried out. Puskesmas state that they have planned infrastructure improvement such as renovating and painting the building and providing more medical equipment and human resources [8].

A study conducted by Xuan, Löfgren, \& Dang (2010) in Vietnam revealed that the special capitation funds in $3 \mathrm{~T}$ 
[4] Shiratori S, Agyekum EO, Shibanuma A, Oduro A, Okawa S, Enuameh $\mathrm{Y}$, et al. Motivation and incentive preferences of community health officers in Ghana: an economic behavioral experiment approach. 2016;

[5] Goodson JD, Bierman AS, Fein O, Rask K, Rich EC, Selker HP. The future of capitation The physician role in managing change in practice. J Gen Intern Med. $2001 \mathrm{Apr} ; 16(4): 250-6$.

[6] Heriawan. Evaluasi Pemanfaatan Dana Kapitasi Jaminan Kesehatan Nasional di Puskesmas Kabupaten Seluma Provinsi Bengkulu. 2016;2016.

[7] Basu S, Philips RS, Song Z, Bitton A, Landon BE. High Levels of capitation payments needed to shift primary care toward proactive team and nonvisit care. Health Aff. 2017;

[8] Luft HS. Economic Incentives to Promote Innovation in Healthcare Delivery. 2009;2497-505.

[9] Xuan N, Löfgren C, Dang H. An assessment of the implementation of the Health Care Funds for the Poor policy in rural Vietnam. Health Policy (New York). 2010;98(1):58-64.

[10] Roehr B. What healthcare reform means for rural America. BMJ. 2013;347(August):1-3.

[11] Mathauer I, Carrin G. The role of institutional design and organizational practice for health financing performance and universal coverage. Health Policy (New York). 2010;99:183-92.

\section{ACKNOWLEDGMENT}

The authors thank to North Nias Distric Health Office and other related parties.

\section{REFERENCES}

[1] Mujiati, Yuniar Y. Availability of Human Resources for Health in Health Facilities in the Era of National Health Insurance in Eight Districts-Cities in Indonesia. Media Litbangkes. 2016;26(4):201-10.

[2] Kemenkes RI. Profil Kesehatan Indonesia 2017. Jakarta: Kementerian Kesehatan Republik Indonesia; 2018.

[3] Murthy S, Rao K, Ramani S, Chokshi M, Khandpur N, Hazarika I. What do doctors want? Incentives to increase rural recruitment and retention in India. 2010;10-1. 